ホ研究助成
成果報
Hosokawa Powder Technology Foundation ANNUAL REPORT

17106

\title{
微粒子吸着界面の界面張力とエマルション形成機構 \\ Interfacial Tension of Particle-modified Interfaces and the Mechanism of Emulsion Formation
}

\author{
研究代表者 Research leader：作花 哲夫 Tetsuo SAKKA \\ 京都大学大学院工学研究科 教授 \\ Graduate School of Engineering, Kyoto University, Professor \\ E-mail: sakka.tetsuo.2a@kyoto-u.ac.jp
}

\section{抄 録}

微粒子の吸着により安定化されたエマルションは Pickering エマルションと呼ばれ, 界面活性剤を 用いることなくエマルションを安定化する手法として注目されている. 微粒子による油水界面の安 定化は, 界面張力の変化をともなうはずであるが, 微粒子吸着界面の界面張力は系統的に理解され ていない. 本研究では, 油水界面の界面張力に対する粒子吸着の効果を明らかにすることを目的と した．粒子の効果を解析しやすいように単分散で球形の粒子を対象とした．また，界面張力の計測 では, プローブが界面に接触する効果を回避するため, キャピラリー波の準弾性光散乱法を用いた。 デカン／水界面の界面張力を吸着粒子の展開量の関数として測定したところ, 粒子展開量とともに 界面張力が減少した，その減少量は，粒子の吸着による安定化自由エネルギーや吸着した粒子間の 斥力相互作用と比較して非常に大きく, 複合的な効果によることが示唆された.

\begin{abstract}
Emulsions stabilized by adsorbing fine particles are called Pickering emulsions, and are attracting attention as a technique for stabilizing emulsions without using a surfactant. The stabilization of the oil-water interface by the fine particles should follow a change in the interfacial tension, but it is not systematically understood. The purpose of this study is to clarify the effect of particle adsorption on the interfacial tension at the oil-water interface. Monodisperse and spherical particles were used to make it easier to analyze the effects of the particles. In the measurement of the interfacial tension, a quasi-elastic light scattering method was employed to avoid the effect of the probe contacting the interface. The interfacial tension at the decane/water interface was measured as a function of the number of adsorbed particles; the interfacial tension decreased with the amount of dispersed particles. The decrease in interfacial tension was much larger than the stabilization free energy due to the adsorption of the particles, or the repulsive interaction between the adsorbed particles, suggesting that the decrease is due to synergetic effects of structural change of the interface.
\end{abstract}




\section{研究背景と目的}

微粒子の吸着により安定化されたエマルショ ンは Pickering エマルション (Pickering S.U., 1907）と呼ばれ，界面活性剂を用いることなく エマルションを安定化する手法として注目され ている, 通常エマルションの形成では, 界面活 性剂により界面張力を低下させ，乳化にともな う自由エネルギーの増加を抑制することが必要 である. Pickeringエマルションの場合でも, 微粒子吸着により液滴の分散による界面自由エ ネルギーの増加がどの程度抑制されるかがエマ ルションの安定化に関係していると考えられる が，微粒子が展開された油水界面の界面張力の 報告例が少なく, 系統的な理解に至っていない，

本研究では, 粒子の効果を解析しやすいよう に, 単分散で球形の粒子を対象とし, 油水界面 の界面張力に対する粒子吸着の効果を明らかに することを目的とした。

界面張力の測定法は Wilhelmy 法を始めさま ざまな方法があるが (Adamson A.W. and Gast A.P., 1997)，その多くは固体プローブを液体表 面（界面）に接触させることによって生じる力 の計測にもとづく，プローブを界面に接触させ ると，プローブと粒子の相互作用により，測定 值が影響を受ける可能性がある。そこで, 本研 究では, キャピラリー波の周波数を準弾性光散 乱法で計測する方法を用いた。この方法は光を プローブとし，また界面の熱励起による波を計 測するため，計測のために系を摚乱しないとい う特徵がある。

\section{研 究方 法}

\section{1. 試料}

直径 $3.3 \mu \mathrm{m}$ の疎水性の球形ポリスチレン （PS）粒子をデカン／水界面に分散させたもの を試料とした．PS 粒子を分散させるときには, JSR 社製のPS 粒子懸濁液 (DYNOSPHERES SS-33-P, 固形分 $1 \mathrm{vol} \%$, 密度 $1.053 \mathrm{gcm}^{-3}$, 粒 子径 $3.34 \pm 0.19 \mu \mathrm{m}$ ) と超純水（Millipore Co.,
Milli-Q Reference A+, 18.2 M $\Omega \mathrm{cm})$ および2-プ ロパノール（Nacalai Tesque, 特級）で調製し た分散溶液を用いた。 PS 粒子, 水, 2-プロパノー ルの体積比は, $0: 1000: 1000$ (以下 $\mathrm{PS}_{0}$ ), 1 : 999: 1000 (以下 $\mathrm{PS}_{1}$ ), 2: $998: 1000$ (以下 $\mathrm{PS}_{2}$ ), 4:996:1000(以下 $\mathrm{PS}_{4}$ ), あるいは $10: 990$ : 1000 (以下 $\mathrm{PS}_{10}$ ) とした。

\section{2. 準弾性光散乱法}

重力などの外力が無視でき, 粘性が小さい場 合, キャピラリー波の分散関倸は,

$$
\omega^{2}=\gamma \boldsymbol{q}^{3} /\left(\rho_{\mathrm{a}}+\rho_{\mathrm{b}}\right)
$$

となる（Levich V.G., 1962）。ここで， $\rho_{\mathrm{a}}$ と $\rho_{\mathrm{b}}$ は それぞれ相 $\mathrm{a}$, 相 $\mathrm{b}$ の密度, $\boldsymbol{q}$ はキャピラリー 波の波数, $\omega$ はキャピラリー波の角周波数であ り, $\gamma$ は界面張力である. 波数 $\boldsymbol{q}$ のキャピラリー 波の周波数 $\omega$ を, 準弾性光散乱によって測定 することで, 界面張力 $\gamma$ を求めることができる.

今，キャピラリー波による光の散乱を考え， 入射光の波数を $\boldsymbol{k}$, 周波数を $f$, 散乱光の波数 を $\boldsymbol{k}$ ’, 周波数を $f^{\prime}$, キャピラリー波の波数を $\boldsymbol{q}$, 周波数を $F(=\omega / 2 \pi)$ とすると,

$$
\begin{aligned}
\boldsymbol{k}^{\prime} & =\boldsymbol{k}+\boldsymbol{q} \\
f^{\prime} & =f+F
\end{aligned}
$$

が成立する， $\boldsymbol{k}$ と と $\boldsymbol{k}$ の間の角度を $\theta$ とすると，

$$
\boldsymbol{q}=(4 \pi / \lambda) \sin (\theta / 2)
$$

である。ここで,入は光の波長である. 式 (4) は, 散乱角を決めることでキャピラリー波の波数 $\boldsymbol{q}$ が決まることを意味している。キャピラリー波 の周波数は, 散乱光の周波数と入射光の周波数 の差 $\left(f^{\prime}-f\right)$ であるので, 両者のビート信号の 周波数から求めることができる。このようにし て求めた波数と周波数から, 式(1) を使って界 面張力が求まる.

図 1 に実験のセットアップを示した (Sakka T. et al., 2006). エタロンを用いて単一縦モード発 振させたアルゴンイオンレーザーを, 石英光学 基板をビームスプリッタとして利用して分割 


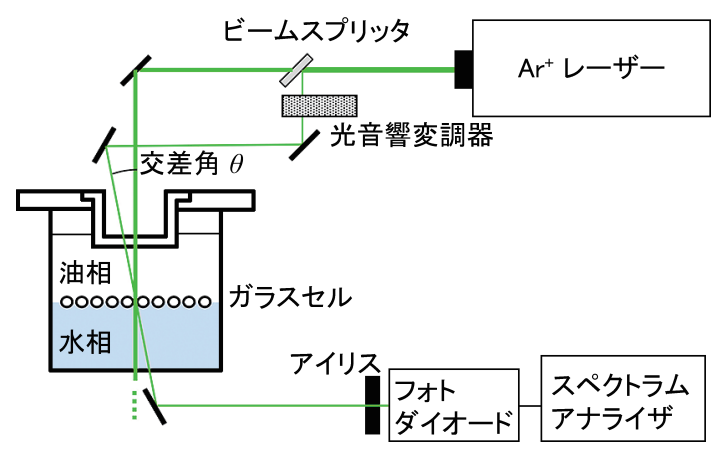

Fig. 1 Experimental setup of quasi-elastic light scattering measurement based on optical heterodyne spectroscopy. The light scattered at the oil-water interface with a certain scattering angle is detected together with a portion of original light (local light) to give frequency shift by the scattering with capillary wave.

し, 反射光を光音響変調器により $80 \mathrm{MHz}$ 変調

し，局所光とした．ビームスプリッタの透過光 は，ガラスセル中の被測定界面に垂直に入射さ せ，界面で散乱させた。局所光は界面の同一位 置に角度 $\theta$ で入射させ，その方向に散乱した光 とともにアバランシェフォトダイオード(APD) で受光したＡPDの信号はデジタルスペクト ラムアナライザーでフーリエ変換され，ビート 信号をスペクトルドメインで得た。この方法で は，局所光と同時に検出される散乱光の散乱角 が，局所光の入射角 $\theta$ と一致することが保証さ れており，qが正確に決まる。なお，局所光は $80 \mathrm{MHz}$ だけ変調されているため, $80 \mathrm{MHz} の$ 前後に現れる散乱光によるビート信号を読み取 り，キャピラリー波の周波数を得た。

\section{3. 接触角の計測}

デカン／水界面に吸着した球形ポリスチレン 粒子の接触角は顕微鏡観察によって求めた. 100 倍の水浸対物レンズを用いて水相側から界 面を顕微観察し，ポリスチレン粒子の水相側に 露出している部分の直径 $d$ を測定した. 粒子が 小さいためメニスカスの効果を無視し，接触角 $\phi$ は $\phi=180^{\circ}-\sin ^{-1}[(d / 2) / R]$ により求めた。こ こで, $R$ は粒子の半径である.
研 究成 果

\section{1. 粒子分散界面の界面張力}

図 2 はポリスチレンを分散させたデカン／水 界面の界面張力の測定結果を, 展開した粒子分 散液の体積（展開量）に対してプロットした図 である， $\mathrm{PS}_{0}$ とあるのは，粒子を含まない2-プ ロパノール水溶液であり，2-プロパノールと水 が体積比で等量含まれている溶液である。粒子 が含まれていなくても展開液の添加にともなっ て界面張力が減少した。このことは，2-プロパ ノールがデカン／水界面に吸着することで界面 を安定化していることを示唆している。これに 対して，粒子を含む2-プロパノール水溶液を 展開した場合, 粒子を含まない場合に比べて界 面張力がより大きく減少した，分散液の展開に よる界面張力の減少は, 分散液中の粒子密度が 大きい場合により顕著であった。このことは， 2-プロパノールの効果だけで界面張力の減少を 説明できないことを示しており，界面に吸着し ている粒子が界面全体の界面張力に影響してい ることが明らかになった。

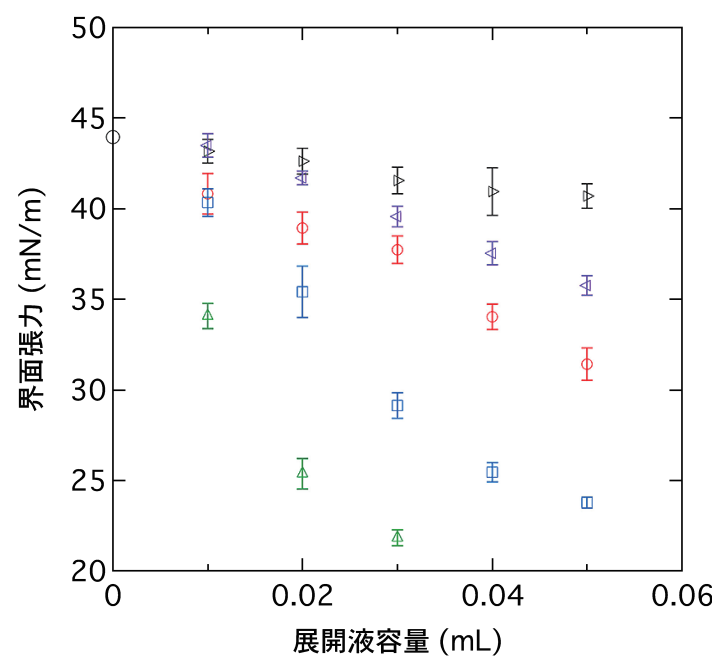

Fig. 2 Experimental results of interfacial tension obtained as a function of the volume of dispersion solution added to the decane/water interface. The dispersion solutions added to the system were, $D$ : $\mathrm{PS}_{0}, \triangleleft: \mathrm{PS}_{1}, \bigcirc: \mathrm{PS}_{2}, \square: \mathrm{PS}_{4}$, and $\triangle: \mathrm{PS}_{10}$. 


\section{2. 粒子の接触角について}

図 3 には, デカン／水界面に $\mathrm{PS}_{2}$ を展開した ときに，吸着したポリスチレン粒子の接触角を 測定した結果を示した。得られた接触角は $135^{\circ}$ 前後と大きく,粒子の体積のほとんど $(80 \%$ 以上）はデカン相側に露出していることがわ かった，接触角は粒子の展開量にほとんど依存 しなかった。このことは，界面における粒子の 密度が変化しても粒子と水相あるいは粒子とデ カン相との親和性の関係は大きく変化しないこ とを示唆している.

\section{3. 考察}

図 2 で粒子の展開量が増加するにしたがって デカン／水界面の界面張力が減少したが, 現在 のところ減少量を定量的に説明できていない 分子の吸着により表面圧が発生する場合，理想 気体の状態方程式のように振る舞うことが知ら れているが, この場合 $10^{23}$ 個といったアボガ ドロ数に近い数によって, 初めて有意な表面圧 をもたらす。

デカン中のポリスチレン粒子（状態 1）が界 面に吸着したとき（状態 2）の自由エネルギー 変化は, 粒子／デカン, 粒子／水, デカン / 水

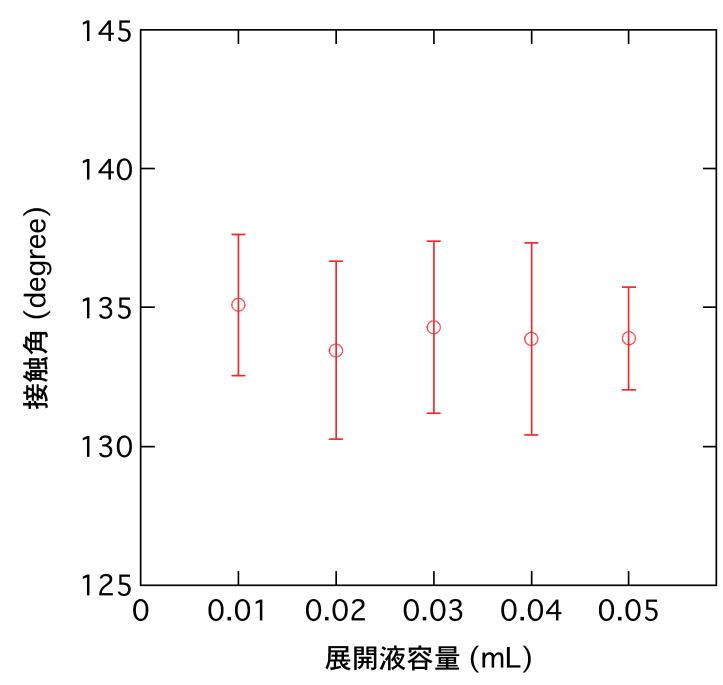

Fig. 3 Contact angle of polystyrene particles at decane/ water interface. Dispersion solution of $\mathrm{PS}_{2}$ is used for this measurement.
の各界面のエネルギー，拉よびYoung の式を 考慮すると,

$$
\Delta G=G_{2}-G_{1}=-\gamma_{\text {ow }}\left(A_{\mathrm{cs}}+A_{\mathrm{pw}} \cos \phi\right)
$$

と表される。ここで, $\gamma_{\mathrm{ow}}$ はデカン／水界面の 界面張力， $A_{\mathrm{cs}}$ は粒子吸着によってデカン / 水 界面が減少する面積, $A_{\mathrm{pw}}$ は粒子／水界面の面 積, $\phi$ は接触角である。 さらに, 粒子の半径 $R$ を用いて表すと，

$$
\Delta G=-\pi R^{2} \gamma_{\text {ow }}(1+\cos \phi)^{2}
$$

となる。この式で, $\phi=131^{\circ}, \gamma_{\mathrm{ow}}=50 \mathrm{mN} / \mathrm{m}$ と すると，粒子の吸着エネルギーは $5 \times 10^{-14} \mathrm{~J}$ と計算される。図 2 の測定結果から, 粒子 1 個 あたりの界面エネルギーに与える効果は $10^{-12} \mathrm{~J}$ 程度と見積られるので，式 (5) および (6) の考 え方では実験結果を説明できない，界面に吸着 されたポリスチレン微粒子間の斥力相互作用 （Sakka T. et al., 2014）を考慮しても，図 2 の界 面張力の低下の大きさは説明できない.

現在, マイクロエマルションの形成が微粒子 によって促進される効果を検討している。例え ば，金微粒子を含むエタノール - シクロヘキサ ン混合液では, 微視的不均一性がより安定化し ていることを示すデー夕が得られている。ポリ スチレン粒子の界面への展開により，デカン／ 水だけでなく粒子近傍の 2-プロパノールも作 用することでマイクロエマルション様の微視的 構造が形成される可能性があるが,このような, 複合的な要因による界面構造形成が界面エネル ギーの低下をもたらしている可能性を考える必 要があるかもしれない

\section{参考文献}

Adamson A.W., Gast A.P., Physical Chemistry of Surfaces, 6th ed., John Wiley \& Sons, Inc., New York (1997), ISBN: 978-0-471-14873-9.

Levich V.G., Physicochemical Hydrodynamics, Prentice-Hall Inc., Englewood Cliffs (1962), ASIN: B0026T3SU2.

Pickering S.U., Emulsions, Journal of the Chemical Society, Transactions, 91 (1907) 2001-2021. https://doi.org/10.1039/СТ9079102001 
Sakka T., Kozawa D., Tsuchiya K., Sugiman N., Øye G., Fukami K., Nishi N., Ogata Y.H., Two-dimensional array of particles originating from dipole-dipole interaction as evidenced by potential curve measurements at vertical oil/water interfaces, Physical Chemistry Chemical Physics, 16 (2014) 16976-16984.

https://doi.org/10.1039/C4CP01710B

\section{外部 発表成果}

\section{口頭・ポスター発表}

1. 宮㟝一輝, 天野健一, 西直哉, 作花哲夫, “二成分系溶媒の微視的不均一性に対する金 ナノ粒子の影響”，第 69 回コロイドおよび
Sakka T., Tanaka K., Shibata Y., Ogata Y.H., Interfacial tension measurement at a flat liquid-liquid interface under electrochemical instability, Journal of Electroanalytical Chemistry, 591 (2006) 168-174.

https://doi.org/10.1016/j.jelechem.2006.04.012

界面化学討論会（Tsukuba, Sept. 18-20, 2018） $3 \mathrm{G} 13$.

2. 宮川翔太, 天野健一, 西直哉, 作花哲夫, “LIBS 計測のための水中分散粒子の光ピン セットによるトラップ領域の検討”, レーザー 学会学術講演会第 39 回年次大会（Tokyo, Sept. 12-14, 2019） 13-3. 